\title{
Conditional Inactivation of Androgen Receptor Gene in the Nervous System: Effects on Male Behavioral and Neuroendocrine Responses
}

\author{
Kalina Raskin, ${ }^{1,2}$ Karel de Gendt, ${ }^{3}$ Anne Duittoz, ${ }^{4}$ Philippe Liere, ${ }^{5}$ Guido Verhoeven, ${ }^{3}$ François Tronche, ${ }^{1,2}$ and \\ Sakina Mhaouty-Kodja ${ }^{1,2}$ \\ ${ }^{1}$ Centre National de la Recherche Scientifique (CNRS) Unité Mixte de Recherche (UMR) 7148, "Génétique Moléculaire-Neurophysiologie et \\ Comportement," and 'Institut de Biologie, Collège de France, 75231 Paris, France, ${ }^{3}$ Laboratory of Experimental Medicine and Endocrinology, Katholieke \\ Universiteit Leuven, 3000 Leuven, Belgium, ${ }^{4}$ CNRS UMR 6175/Institut National de la Recherche Agronomique, 37380 Nouzilly, France, and ${ }^{5}$ MR 788 - \\ Inserm-Université Paris XI, 94276 Kremlin Bicêtre, France
}

Testosterone $(\mathrm{T})$ profoundly influences central sexual differentiation and functions. In the brain, $\mathrm{T}$ signals either directly through androgen receptor (AR) or indirectly through estrogen receptor (ER) following aromatization into E2 (17- $\beta$-estradiol). As T, through AR, also controls peripheral male sexual differentiation, the relative contribution of central AR in T-mediated regulation of behavioral and neuroendocrine responses still remains unclear. To address this question, we generated, by using Cre-loxP technology, mice selectively lacking AR expression in the nervous system. The mutant male urogenital tract was normally developed, and mice were able to produce offspring. Nonetheless, sexual motivation and performance as well as aggressive behaviors were affected. Only a low percentage of males displayed a complete sexual behavior and offensive attacks. The latency to show masculine behaviors was increased and copulation length prolonged. Erectile activity during mating was also altered. These alterations occurred despite increased levels of $\mathrm{T}$ and its metabolites, and an unaffected number of $\mathrm{ER} \alpha$-immunoreactive cells. Olfactory preference and neuronal activation, mapped by Fos immunoreactivity, following exposure to estrus female-soiled bedding were also normal. At comparable $\mathrm{T}$ levels, greater differences in masculine behaviors were observed between gonadectomized control and mutant males. $A R$ invalidation in the nervous system also disrupted the somatotropic axis since mutant males exhibited growth retardation and decreased serum levels of insulin-like growth factor I. Our findings show that central AR is required in T-induced regulation of male-typical behaviors and gonadotrope and somatotropic axes. This genetic model offers a unique opportunity in the understanding of AR's role in cerebral functions of T.

\section{Introduction}

Testosterone (T) exerts permanent (organizational) effects on the developing male nervous system during the perinatal period and transient (activational) roles in adulthood (Phoenix et al., 1959). In rodents, the prenatal and neonatal T surges masculinize neural circuitries, leading to an enhancement of behavioral patterns that are exclusively elicited by males. Indeed, a wide range of behaviors (sex, aggression, juvenile play...) and neuroendocrine functions (feedback effect of steroids on gonadotropin release, growth) are sexually dimorphic.

Received Jan. 19, 2009; revised Feb. 20, 2009; accepted Feb. 20, 2009.

This work was supported by the Centre National de la Recherche Scientifique (CNRS) and Collège de France. We thank Drs. R. Counis and G. Garrel [CNRS Unité Mixte de Recherche (UMR) 7079, Paris, France] for providing the monoclonal anti-LH $\beta$; Dr. Caraty A. [CNRS UMR 6175/Institut National de la Recherche Agronomique (INRA), Nouzilly France) for anti-GnRH; and Dr. M. Schumacher, A. Pianos, A. Cambourg, and B. Eychenne (UMR 788-InsermUniversité Paris XI, Kremlin Bicêtre, France) for intratesticular steroid content measurements. We are also indebted to Dr. 0. Rampin (UMR1197 INRA-Universite Paris 11, Jouy-en-Josas, France) for helpful discussions on erection.

Correspondence should be addressed to either Sakina Mhaouty-Kodja or François Tronche, Centre National de la Recherche Scientifique Unité Mixte de Recherche 7148, Génétique Moléculaire-Neurophysiologie et Comportement Collège de France, 11 place Marcelin Berthelot, 75231 Paris Cedex 05, France. E-mail: sakina.mhaoutykodja@college-de-france.fr or françois.tronche@gmail.com.

DOl:10.1523/JNEUROSCI.0296-09.2009

Copyright $\odot 2009$ Society for Neuroscience $\quad$ 0270-6474/09/294461-10\$15.00/0
In the brain, $\mathrm{T}$ can signal either directly through activation of androgen receptor (AR), or indirectly via stimulation of estrogen receptors (ERs) following conversion into estradiol by aromatase cytochrome $\mathrm{P}-450$ enzyme (Ar). AR, $\mathrm{ER} \alpha$, and $\mathrm{ER} \beta$ are members of the nuclear receptor superfamily and regulate target genes at a transcriptional level (Matsumoto et al., 2003). To delineate the relative importance of the direct signaling through AR versus the indirect pathway through ER in androgen-mediated regulation of brain functions, genetic models were studied. Data from knock-out (KO) mice ubiquitously lacking Cyp19 ar (arKO) or $E R \alpha(\mathrm{ER} \alpha \mathrm{KO})$ indicated that $17-\beta$-estradiol (E2) deriving from neural aromatization of $\mathrm{T}$ and $\mathrm{ER} \alpha$ signaling pathway play a key role in the expression of sexual and aggressive behaviors (Ogawa et al., 1997; Wersinger et al., 1997; Bakker et al., 2002). Unfortunately, a better understanding of the real involvement of cerebral AR functions in vivo was hampered by the complex phenotype of Tfm (testicular feminization mutation) mice carrying spontaneously mutated $A R$ gene (Lyon and Hawkes, 1970) and ubiquitous ARKO mice (Sato et al., 2003; Chang et al., 2004; De Gendt et al., 2004). Indeed, genetic (XY) males of both models display a complete androgen insensitivity phenotype with female-typical external appearance, small cryptorchidic azoospermic testes, and low 
levels of circulating T. Due to the lack of external genitals, male sexual behavior of Tfm and ARKO mice is limited to coital (mounts and thrusts) behavior as previously described (Ono et al., 1974; Sato et al., 2004). Furthermore, given the critical role of $\mathrm{T}$ in several peripheral functions related or not to reproduction, it is difficult to distinguish, in these genetic models, between its central and peripheral mediated effects.

Therefore, to define more precisely the specific role of central $\mathrm{AR}$ in T-dependent regulation of male behaviors and neuroendocrine functions, we generated mice lacking $A R$ in the nervous system. For this purpose, we crossed floxed AR mice (De Gendt et al., 2004) with transgenic mice expressing Cre recombinase driven by the promoter and the nervous system-specific enhancer of rat nestin (Nes) in neuronal and glial precursor cells (Tronche et al., 1999). The obtained $\mathrm{AR}^{\mathrm{fl}} / \mathrm{Y}$, Nes-Cre $\left(\mathrm{AR}^{\mathrm{Nes} C r e}\right)$ males, unlike ARKO mice, had a normal development of the urogenital tract and were able to produce offspring with reduced fertility. Nevertheless, they exhibited impaired sexual and aggressive behaviors despite high levels of $\mathrm{T}$ and its metabolites [5- $\alpha$ dihydrotestosterone (DHT) and E2]. They also showed growth retardation and altered growth hormone $(\mathrm{GH}) /$ insulin-like growth factor I (IGF-I) system.

\section{Materials and Methods}

Generation of mice with conditional inactivation of AR gene in the nervous system

Mutant $A R^{\text {NesCre }}$ mice and their control $\left(\mathrm{AR}^{\mathrm{fl}} / \mathrm{Y}\right)$ littermates, with a genetic mixed background (C57BL/6 and $129 \mathrm{SvEv})$, were obtained from crossings of $\mathrm{AR}^{\mathrm{Nes} C r e}$ males with $\mathrm{AR}^{\mathrm{fl}} / \mathrm{AR}^{\mathrm{fl}}$ females. Mice were weaned at $21-25 \mathrm{~d}$ of age and group housed under a controlled photoperiod $(12 \mathrm{~h}$ light/12 h dark cycle-lights on at 7:00 A.M. $)$ and temperature $\left(22^{\circ} \mathrm{C}\right)$ and given ad libitum access to food and water. The presence of Cre transgene was detected by dot blot analysis and $\mathrm{AR}^{\mathrm{fl}}$ allele by PCR as previously described (De Gendt et al., 2004). Cre-mediated excision of $\mathrm{AR}^{\mathrm{fl}}$ allele was found only in neuronal tissues. The genetic sex was determined by using specific primers for Sry and NDS genes, located, respectively, on the Y and X chromosomes (Kunieda et al., 1992). All studies were performed on 2- to 5-month-old animals, in accordance with the National Institutes of Health Guide for the Care and Use of Laboratory Animals.

\section{Western blot analysis}

Brain, skeletal muscle, and testis were dissected and stored at $-80^{\circ} \mathrm{C}$. Tissues were homogenized in buffer ( $2 \%$ SDS, 50 mM DTT, $62.5 \mathrm{~mm}$ Tris, $\mathrm{pH} 6.8,10 \%$ glycerol) containing a mixture of protease inhibitors (Roche). Samples were then boiled for $5 \mathrm{~min}$ and centrifuged at $7500 \times$ $g$ for $10 \mathrm{~min}$ at $4^{\circ} \mathrm{C}$. Supernatants were collected, and protein concentrations were determined using a Bradford assay (Bradford, 1976). Samples (35 $\mu \mathrm{g}$ of proteins for brain and skeletal muscle and $15 \mu \mathrm{g}$ for testis) were then loaded and separated on a $7.5 \%$ polyacrylamide gel. After transfer onto a nitrocellulose membrane, the blot was probed with 1:200 diluted polyclonal antibody directed against the N-terminal epitope of AR (Sc816, Santa Cruz Biotechnology) and 1:1000 diluted anti-actin antibody (Sigma). After incubation with peroxidase-conjugated secondary antibody (GE Healthcare) diluted at 1:5000, signals were visualized by using ECL Plus detection kit (GE Healthcare).

\section{Immunohistochemistry}

Animals were killed and transcardially perfused with a solution of $4 \%$ paraformaldehyde (PFA) in PBS. Brains were sliced into $30 \mu \mathrm{m}$ coronal sections and stored in $0.5 \%$ PFA. Pituitary glands were dissected and fixed in $4 \%$ PFA for $1 \mathrm{~h}$ and washed three times in PBS for $20 \mathrm{~min}$ at $4^{\circ} \mathrm{C}$. After an overnight incubation in $18 \%$ saccharose at $4^{\circ} \mathrm{C}$, pituitary glands were sliced $(7 \mu \mathrm{m})$. Testes were fixed in Bouins fluid (for $100 \mathrm{ml}: 75 \mathrm{ml}$ of saturated picric acid, $25 \mathrm{ml}$ of formaldehyde $37 \%, 5 \mathrm{ml}$ of glacial acetic acid) overnight at $4^{\circ} \mathrm{C}$, transferred to $70 \%$ ethanol at $4^{\circ} \mathrm{C}$, then processed into paraffin wax and sliced into $5 \mu \mathrm{m}$ sections.
Brain and pituitary sections were rinsed in PBS and treated with $1 \%$ $\mathrm{H}_{2} \mathrm{O}_{2}$ in PBS for $30 \mathrm{~min}$, then incubated for $2 \mathrm{~h}$ with $5 \%$ normal goat serum (NGS, Sigma-Aldrich) in PBST (PBS/0.1\% Triton X-100). Testis sections were first dewaxed after heat-induced antigen retrieval for $5 \mathrm{~min}$ in $0.01 \mathrm{M}$ citrate buffer, $\mathrm{pH} 6$, in a microwave oven. Sections were incubated at $4^{\circ} \mathrm{C}$ for $36 \mathrm{~h}$ with 1:200 diluted rabbit anti-AR or anti-ER $\alpha$ (Santa Cruz Biotechnology), or overnight with 1:500 diluted anti-c-fos antibody (Abcam). Immunostaining was then performed with biotinylated goat anti-rabbit (1:400, Vector Laboratories) for $2 \mathrm{~h}$. Bound antibodies were visualized by $30 \mathrm{~min}$ of incubation with the biotin-streptavidin complex reagent (ABC kit; Vector Laboratories), followed by color development with 3,3'-diaminobenzidine tetrahydrochloride chromogenic substrate (DAB) from Sigma-Aldrich. For immunofluorescence, pituitary sections were incubated overnight with anti-AR and then $1 \mathrm{~h}$ with mouse anti-luteinizing hormone (LH) (1:300, gift from Drs. R. Counis and G. Garrel, CNRS, Paris, France) in PBST with $1 \%$ NGS. They were then incubated for $2 \mathrm{~h}$ with 1:500 diluted anti-mouse Alexa 488 and anti-rabbit Cy3 secondary antibodies (Invitrogen). For quantification of $\mathrm{ER} \alpha$ immunoreactivity, stained sections were matched on anatomical landmarks and compared across animal groups by tallying the number of labeled cells in each region.

\section{Fertility study}

Each control or mutant male ( 2 months old) was mated with two control females for a period of 4 months. The total number of litters and pups per male was recorded at birth.

\section{Sperm count}

Epididymides were dissected and cut into small pieces in PBS and left to incubate at $37^{\circ} \mathrm{C}$ for $10 \mathrm{~min}$. After $5 \mathrm{~min}$ of centrifugation at room temperature at $100 \times g$, the supernatant was removed and 10 -fold diluted. Spermatozoa were counted in a hemocytometer with a light microscope.

\section{Measurements of hormones and IGF-I levels and gonadotropin-} releasing hormone and $T$ contents

Blood samples were centrifuged at $4500 \times g$ for $10 \mathrm{~min}$ at $4^{\circ} \mathrm{C}$, and sera were stored at $-20^{\circ} \mathrm{C}$ until analysis. $\mathrm{LH}$, follicle-stimulating hormone (FSH), T, E2, and IGF-1 levels were measured by using commercially available RIA kits (Biocode-Hycel for LH and FSH, Biosource International for T and Diagnostic Systems Laboratories for E2 and IGF-1). Assay sensitivities were $0.14 \mathrm{ng} / \mathrm{ml}, 0.2 \mathrm{ng} / \mathrm{ml}, 0.05 \mathrm{ng} / \mathrm{ml}, 2.2 \mathrm{pg} / \mathrm{ml}$, and $21 \mathrm{ng} / \mathrm{ml}$, and interassay coefficients of variation were $12.2 \%, 8.5 \%$, $5.5 \%, 8 \%$, and $6.7 \%$ for LH, FSH, T, E2, and IGF-1, respectively.

For gonadotropin-releasing hormone (GnRH) content, the hypothalamus was dissected on ice from the ventral surface of the brain and rapidly frozen at $-80^{\circ} \mathrm{C}$. Tissue samples were homogenized in $0.1 \mathrm{~N} \mathrm{HCl}$ containing a mixture of protease inhibitors before adding $\mathrm{NaOH}$ to bring the $\mathrm{pH}$ to 7 as previously described (Moore and Wray, 2000). The homogenates were then centrifuged at $4^{\circ} \mathrm{C}$ for $10 \mathrm{~min}$, and the supernatants were stored at $-80^{\circ} \mathrm{C}$ until RIA analysis. Samples were resuspended in PBS-gelatin buffer, and GnRH concentration was measured in $100 \mu \mathrm{l}$ duplicate aliquots as described previously (Caraty et al., 1995). GnRH assay sensitivity was $0.2 \mathrm{pg} / \mathrm{ml}$, and the mean interassay and intra-assay coefficients of variation were $13 \%$ and $9 \%$, respectively. The used GnRHBDS037 antibody is specific to the C-terminal moiety and also binds pro-GnRH and Hyp9-GnRH.

Intratesticular contents of $\mathrm{T}$ and DHT were measured by gas chromatography-mass spectrometry as previously described (Liere et al., 2000; Meffre et al., 2007).

Ten to 15 animals per genotype were used for each assay.

\section{Male-typical behaviors}

Analyses were conducted in Plexiglas cages under red-light illumination $2 \mathrm{~h}$ after lights off and were videotaped for further analysis.

Sexual behavior. Naive males were individually housed $3 \mathrm{~d}$ before testing. In experiment 1 , males were tested three times with an interval of 2-3 d. Briefly, subjects were first habituated to Plexiglas cages placed on a $45^{\circ}$ inclined mirror to allow ventral viewing as previously described (Wersinger and Rissman, 2000b). Tests lasted $30 \mathrm{~min}$ after the introduction of 
the receptive female if no sexual behavior was displayed. If a mounting episode occurred during this period, the test was extended for 30 additional min or until the male ejaculated. In the latter case, the subject was no longer tested during the next sessions. For males that exhibited sexual behavior on test 2 or 3 , the latencies to mount, intromit, thrust, and ejaculate were cumulative. In experiment 2 , each male was tested once in its housing cage for $10 \mathrm{~h}$ after female introduction.

Stimulus C57BL/6J females were ovariectomized and implanted with SILASTIC implants filled with $50 \mu \mathrm{g}$ of E2-benzoate (Sigma-Aldrich) in $30 \mu \mathrm{l}$ of sesame oil. Four to five hours before the tests, females were subcutaneously administered with $1 \mathrm{mg}$ of progesterone (SigmaAldrich) in $100 \mu \mathrm{l}$ of sesame oil. Female receptivity was screened with sexually experienced males before the beginning of the test. At the end of experiment 2, females were still receptive when put in the presence of sexually experienced males.

Erectile activity. The latency to the first grooming erection, and the time spent in erection after each mount with intromission were measured in experiment 2. Erection was scored when the male stood on its hindlimbs, bent its body forward, head down to reach the penis, and performed genital grooming while displaying hip movements, as previously described (Rampin et al., 2003; Rampin et al., 2006).

Olfactory preference. One week after sexual behavior tests, males were placed for $10 \mathrm{~min}$ in cages where three containers filled with clean, malesoiled, or female-soiled bedding were equidistantly placed. Animals were first habituated for 2 consecutive days in the same paradigm with only clean bedding for $10 \mathrm{~min}$. The time spent sniffing each container was recorded. Male-soiled bedding was obtained from animals placed in a cage with clean bedding $24 \mathrm{~h}$ before the test. Female-soiled bedding was obtained from five group-housed E2-treated females, injected with progesterone $6 \mathrm{~h}$ before bedding collection.

Aggression. Males, individually housed for 2 weeks without bedding changes, were tested in a resident-intruder paradigm in their home cages for 3 consecutive days by using A/J mice (The Jackson Laboratory) as intruders. The A/J mouse strain was chosen on the basis of its low scores of aggression (Le Roy et al., 2000). In fact, we never noted an aggressive behavior from $\mathrm{A} / \mathrm{J}$ mice toward resident animals. Each test was performed with a different intruder. The test was stopped immediately after the first offensive attack (defined by biting and wrestling) or after $10 \mathrm{~min}$ when no attack occurred. In the latter case, the latency was 600 s. For gonadectomized and $\mathrm{T}$-treated mice, tests lasted $10 \mathrm{~min}$. The latency to the first aggressive act (tail rattling, biting, lunge, offensive attack), the total aggression duration, and the number of offensive attacks and lunge and bites aggression bouts displayed toward the intruder mice were scored for each resident animal.

\section{Elevated plus maze}

Animals (10 per genotype) were tested for their behavior in the elevated plus maze (EPM). Mice were brought into the test room at least $1 \mathrm{~h}$ before the testing onset. Analysis was performed for $10 \mathrm{~min}$ under controlled light conditions (500 lux) and started $4 \mathrm{~h}$ before dark. At the beginning of the test, each mouse was placed in the central area. The time spent as well as the number of entries into the open arms were registered.

\section{Locomotor activity}

Locomotor activity of animals was analyzed in a computed circular corridor as previously described (Salomon et al., 2006). Briefly, mice were introduced in a circular corridor made of two concentric cylinders crossed by four diametrically opposite infrared beams (Imetronic). The locomotor activity was counted when animals interrupted two successive beams and thus had traveled a quarter of the circular corridor. In the device, the lighting was programmed on the usual dark:light cycle. Spontaneous activity was recorded for $14 \mathrm{~h}$.

Since aggressive behavior, anxiety state, and locomotor activity were comparable between naive and sexually experienced males, we presented only the results obtained on sexually experienced mice.

\section{T and DHT treatments}

Naive males were castrated at 8 weeks of age and implanted with SILASTIC tubes containing $10 \mathrm{mg}$ of either T or DHT (Sigma-Aldrich). Two weeks later, animals were tested in the behavioral tests.

\section{Statistics}

The percentages of animals showing behaviors were compared by Fisher exact tests. All other data are expressed as means \pm SEM. Analysis of olfactory preference and aggression was performed by a two-way ANOVA for repeated measures for the main effects of genotype and bedding or genotype and test day, respectively, as factors, followed by Bonferroni tests as post hoc comparisons. Data of nonrepeated measurements were analyzed by one-way ANOVA or Student's $t$ test for unpaired data. $p$ value $<0.05$ was considered significant.

\section{Results}

\section{Generation and characterization of conditional mutant mice lacking $A R$ in the nervous system}

To selectively inactivate $A R$ gene in the nervous system, we crossed females carrying floxed $A R$ gene allele (De Gendt et al., 2004) with transgenic male mice expressing Cre recombinase under the control of the rat Nes promoter and neural-specific enhancer (Tronche et al., 1999).

Analysis by Western blotting indicated the presence of 110 $\mathrm{kDa} \mathrm{AR}$ protein in the testis and skeletal muscle of both control $\left(\mathrm{AR}^{\mathrm{fl}} / \mathrm{Y}\right)$ and $\mathrm{AR}^{\mathrm{Nes} C r e}$ mice (Fig. $\left.1 A\right)$. Nuclear AR protein was indeed present in testicular Sertoli cells, peritubular myoid cells, and Leydig cells as well as in $\mathrm{LH} \beta$-positive gonadotrope cells of both genotypes (Fig. $1 B, C$ ). In the brain, AR signal was detected in control but not in mutant animals (Fig. $1 A$ ). Detailed immunohistochemical studies revealed a high nuclear AR expression in several brain regions of control mice (Fig. 1D). Similar distribution and density of nuclear AR expression were observed in the brain of $\mathrm{AR}^{+} / \mathrm{Y}$ and $\mathrm{AR}^{+} / \mathrm{Y}$ mice carrying Nes-Cre transgene (data not shown). In $\mathrm{AR}^{\mathrm{Nes} C r e}$ animals, $\mathrm{AR}$ protein was completely lost in the CA1 region of the hippocampus, cortex, medial amygdala (MA), cortical amygdala, lateral septum, and bed nucleus of stria terminalis (BNST) (Fig. 1D). In the hypothalamus, $\mathrm{AR}$ expression also disappeared in many regions, including the medial preoptic area (MPOA), ventromedial hypothalamus, and arcuate nucleus (Fig. 1D); only a few scattered cells retained $\mathrm{N}$-terminal AR labeling in the anterior and lateral hypothalamus.

Altogether, these results indicate that $A R$ was selectively disrupted in the brain of $\mathrm{AR}^{\mathrm{Nes} C r e}$ males, including regions important in the regulation of neuroendocrine and behavioral functions related to reproduction, such as mating and aggression (MA, lateral septum, BNST, MPOA, and ventromedial hypothalamus), and areas involved in learning and memory (cortex and hippocampus).

\section{Effects of nervous system $A R$ disruption on male neuroendocrine functions}

Elevated ranges of T, DHT, E2, and LH in AR ${ }^{\text {NesCre }}$ males

Comparison of phenotypic and genetic sex indicated a normal sex ratio of $1: 1$ male/female for $\mathrm{AR}^{\mathrm{Nes} C r e}$ mice. In addition, adult $\mathrm{AR}^{\mathrm{Nes} C r e}$ males showed normal development of external genitals (Fig. 2A) and urogenital tract (Fig. 2B). This clearly indicates that conditional AR gene inactivation in the nervous system did not interfere with male sexual differentiation of the urogenital system. Despite a slight reduction of testicular weight $(0.29 \pm 0.01 \%$ of body weight vs $0.35 \pm 0.01 \%$; $p<0.05)$, mutant males had, respectively, 2.6-fold and twofold higher gonadal contents of $\mathrm{T}$ $(70.9 \pm 16.9 \mathrm{ng} / \mathrm{g}$ vs $26.7 \pm 3.3 \mathrm{ng} / \mathrm{g} ; p<0.05)$ and its metabolite DHT $(8.4 \pm 1.3 \mathrm{ng} / \mathrm{g}$ vs $3.7 \pm 0.9 \mathrm{ng} / \mathrm{g} ; p<0.01)$ than controls. Circulating levels of $\mathrm{T}$ were also significantly enhanced by fourfold in $\mathrm{AR}^{\text {NesCre }}$ mice $(3.9 \pm 0.6 \mathrm{ng} / \mathrm{ml}$ vs $1.3 \pm 0.1 \mathrm{ng} / \mathrm{ml} ; p<$ 0.01 ), which is in good correlation with the increased weight of the androgen-sensitive seminal vesicles $(0.65 \pm 0.02 \%$ of body weight vs $0.40 \pm 0.02 \%$; $p<0.0001)$. Serum levels of E2, another 


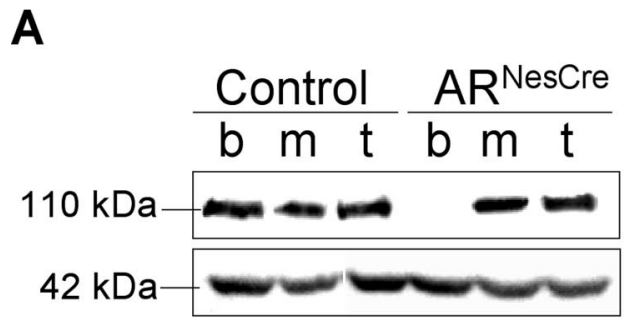

D
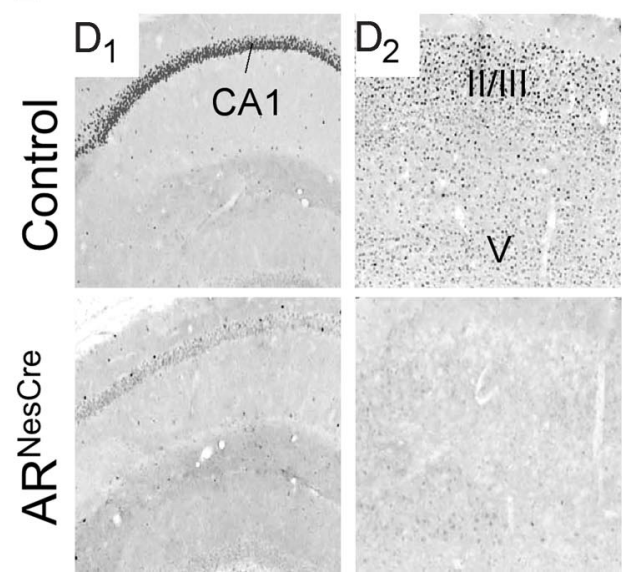

B

Control
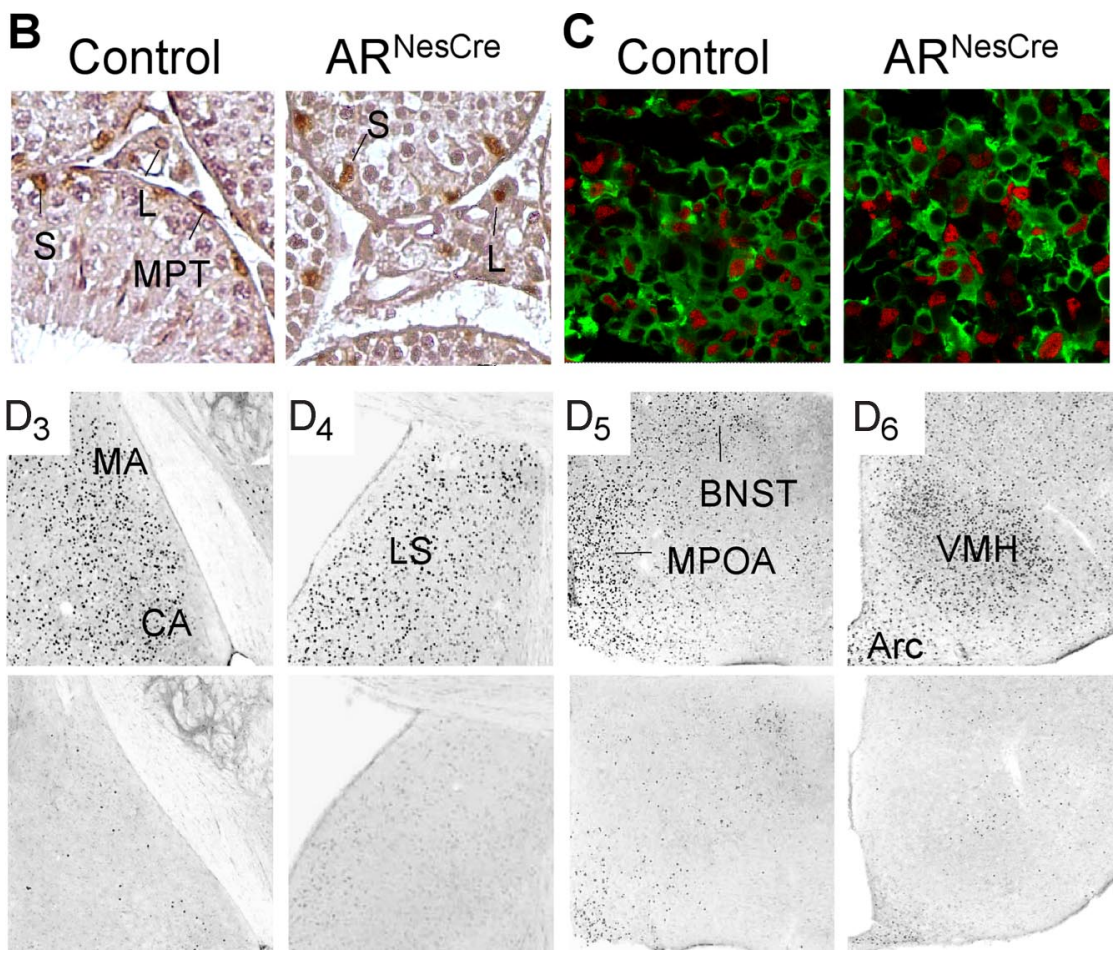

Figure 1. AR gene disruption is specific to the nervous system in $A R^{\text {Nes }}(r e$ mice. $A$, Western blotting of the $110 \mathrm{kDa} A R$ and $42 \mathrm{kDa}$ actin proteins from brain (b), skeletal muscle ( $\mathrm{m}$ ), and testicular

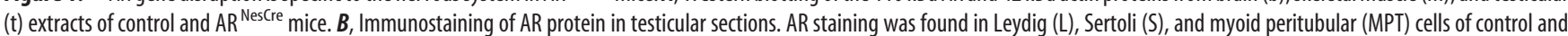

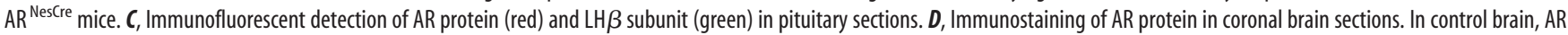

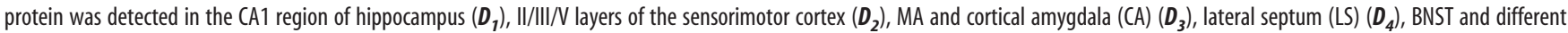
hypothalamic regions, including the MPOA $\left(\boldsymbol{D}_{5}\right)$, and arcuate nucleus (Arc) and ventromedial hypothalamus (VMH) $\left(\boldsymbol{D}_{6}\right)$. The corresponding AR ${ }^{\text {Nescre }}$ sections show no specific AR immunostaining.

A

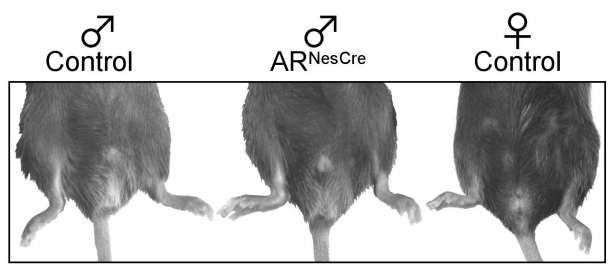

B

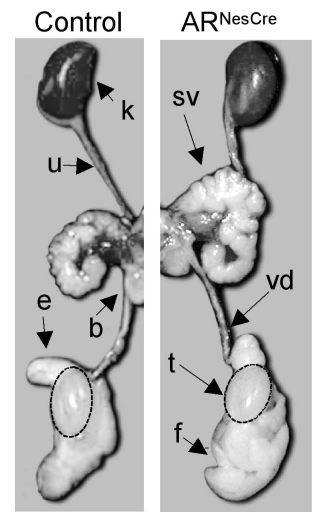

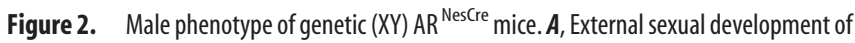
$A R^{\text {Nescre }}$ males was compared with control male and female littermates at $3-4$ months of age. Anogenital distance was similar between control $(10.8 \pm 0.6 \mathrm{~mm})$ and mutant $(11.1 \pm 1.2$ $\mathrm{mm}$ ) males ( $n=7-10$ per genotype). $\boldsymbol{B}$, Urogenital tract of control and AR ${ }^{\text {Nescre }}$ males. k, Kidney; sv, seminal vesicle; vd, vas deferens; $t$, testis; $b$, bladder; $f$, fat tissue; e, epididymis; $u$, ureter.

metabolite of $\mathrm{T}$, were also significantly augmented by $42 \%$ in $\operatorname{AR}^{\text {NesCre }}$ mice $(7.8 \pm 0.7 \mathrm{pg} / \mathrm{ml}$ vs $5.5 \pm 0.3 \mathrm{pg} / \mathrm{ml} ; p<0.01)$.

In males, the testicular synthesis of $\mathrm{T}$ is under the control of the hypothalamic GnRH and pituitary LH. The liberated T acts,
Table 1. Four month fertility test and epididymal sperm count

\begin{tabular}{lccc}
\hline & & \multicolumn{1}{l}{$A R^{\text {Nescre }}$} \\
\cline { 3 - 4 } & Control & Fertile & Hypofertile \\
\hline Fertility & & & \\
$\quad$ Total number of pups & $43.2 \pm 3.0(6)$ & $42.6 \pm 1.3(5)$ & $22.5 \pm 4.2^{*}(4)$ \\
$\quad$ Total number of litters & $5.8 \pm 0.2(6)$ & $6.0 \pm 0.4(5)$ & $4.5 \pm 0.9(4)$ \\
$\quad$ Litter size & $8.0 \pm 0.4(6)$ & $6.8 \pm 0.4^{*}(5)$ & $5.1 \pm 0.6^{*}(4)$ \\
Sperm count & & \\
$\quad$ No. of spermatozoa $\left(\times 10^{6} / \mathrm{ml}\right)$ & $14.1 \pm 1.1(26)$ & $5.8 \pm 0.6^{*}(21)$ \\
\hline Values are means \pm SEM of the indicated number $(n)$ of control and AR & \\
\hline Nescre & mice. ${ }^{*} p<0.002$ versus control.
\end{tabular}

in turn, to reduce both GnRH and LH release. In mutant animals, LH levels were also increased by twofold $(2.0 \pm 0.2 \mathrm{ng} / \mathrm{ml}$ vs $0.98 \pm 0.06 \mathrm{ng} / \mathrm{ml} ; p<0.001)$ while FSH levels were at the normal range $(38.2 \pm 6.00 \mathrm{ng} / \mathrm{ml}$ for mutants vs $36.4 \pm 6.0 \mathrm{ng} / \mathrm{ml}$ for controls). No significant differences were observed in the hypothalamic GnRH content between control and mutant animals $(499.6 \pm 78.5 \mathrm{pg} / \mathrm{animal}$ for controls vs $426.1 \pm 36.6 \mathrm{pg} / \mathrm{animal}$ for mutants).

When tested in continuous mating, $\mathrm{AR}^{\mathrm{Nes} C r e}$ males were able to produce offspring, but $45 \%$ of them were hypofertile with a significantly decreased litter size and total number of pups (Table $1) . \mathrm{AR}^{\text {NesCre }}$ males had also consistently lower (2.4-fold decrease) spermatozoa number in the epididymides (Table 1 ).

Growth retardation and reduced serum IGF-I levels in AR NesCre males

Mutant males exhibited a significant decrease of body weight $(-16 \%, p<0.05)$ (Fig. $3 A)$ and length $(-6.5 \%)$ at $3-4$ months of age $(94.0 \pm 1.2 \mathrm{~mm}$ vs $99.8 \pm 1.0 \mathrm{~mm} ; p<0.001)$. Analysis of body composition indicated that fat, muscle, and bone masses, 


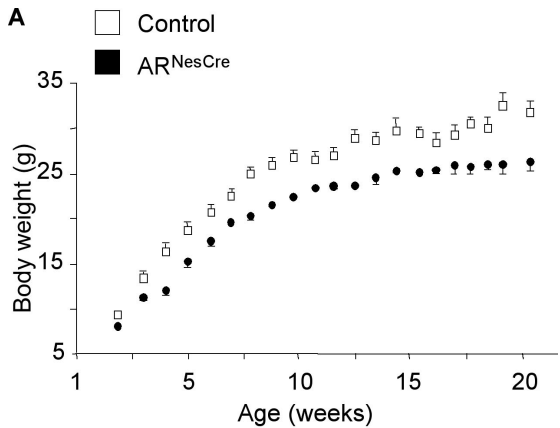

B

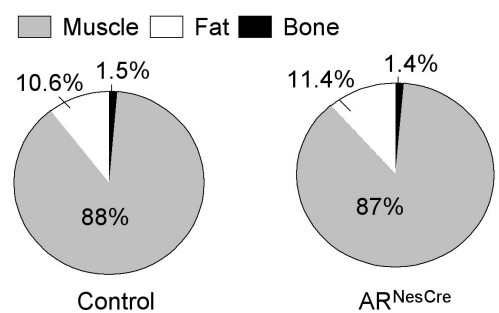

Figure 3. Growth of $A R^{\text {Nescre }}$ mice. $A$, Control and $A R^{\text {Nescre }}$ males from the same litters $(n=$ 15-19 per genotype) were weekly weighed. The growth curves are significantly different ( $p<$ 0.05 ). $\boldsymbol{B}$, Body composition of live adult ( 3 months old) males ( $n=5$ per genotype) was analyzed by using a Piximus densitometer (Lunar Corporation). Muscle, fat, and bone masses are given as percentages of total body weight.

expressed as percentages of total body weight, were not significantly different between control and $\mathrm{AR}^{\mathrm{NesCre}}$ mice (Fig. $3 B$ ). To investigate whether the somatotropic axis was altered in mutant males, we measured serum levels of IGF-I, the key mediator of $\mathrm{GH}$ actions. We thus found that it was reduced by twofold in $\mathrm{AR}^{\text {NesCre }}$ males in comparison with their control littermates $(255.6 \pm 26.8 \mathrm{ng} / \mathrm{ml}$ vs $525.8 \pm 19.7 \mathrm{ng} / \mathrm{ml} ; p<0.0001)$.

\section{Nervous system $A R$ disruption impaired masculine behaviors} Sexual behavior

We investigated the effects of nervous system $A R$ gene inactivation on the expression of male sexual behavior by using two protocols. In 30 min tests (experiment 1), 55\% of control males exhibited a complete sexual behavior with mounting, intromissions, pelvic thrusts, and ejaculation (supplemental Table 1, available at www.jneurosci.org as supplemental material). In contrast, none of the tested $\mathrm{AR}^{\text {NesCre }}$ males showed male sexual behaviors, even mounting attempts (supplemental Table 1, available at www.jneurosci.org as supplemental material). Since $\mathrm{AR}^{\mathrm{Nes} C r e}$ males were able to produce offspring in continuous fertility test, we measured sexual behavior of another group of naive control and mutant males for $10 \mathrm{~h}$ from the introduction of receptive females (experiment 2 ). In these experimental conditions, $100 \%$ of control animals mounted, intromitted, performed pelvic thrusts, and ejaculated (Fig. $4 \mathrm{~A}$ ). In contrast, only $55 \%$ of $\mathrm{AR}^{\mathrm{Nes} C r e}$ males exhibited mounting, intromissions, and thrusts with $33 \%$ reaching ejaculation while the $45 \%$ remaining mutant males did not show any sexual behavior attempt within the $10 \mathrm{~h}$ of the test (Fig. $4 A$ ). In addition, the latencies to the first mount, intromission, pelvic thrusting, and ejaculation were significantly greater for mutant animals (Fig. $4 B, C$ ). The performance of mutant mice was also altered since they exhibited a prolonged mating behavior (Fig. 4C, Table 2). Even those that showed a complete sexual behavior reached ejaculation much more slowly than their control littermates. This was
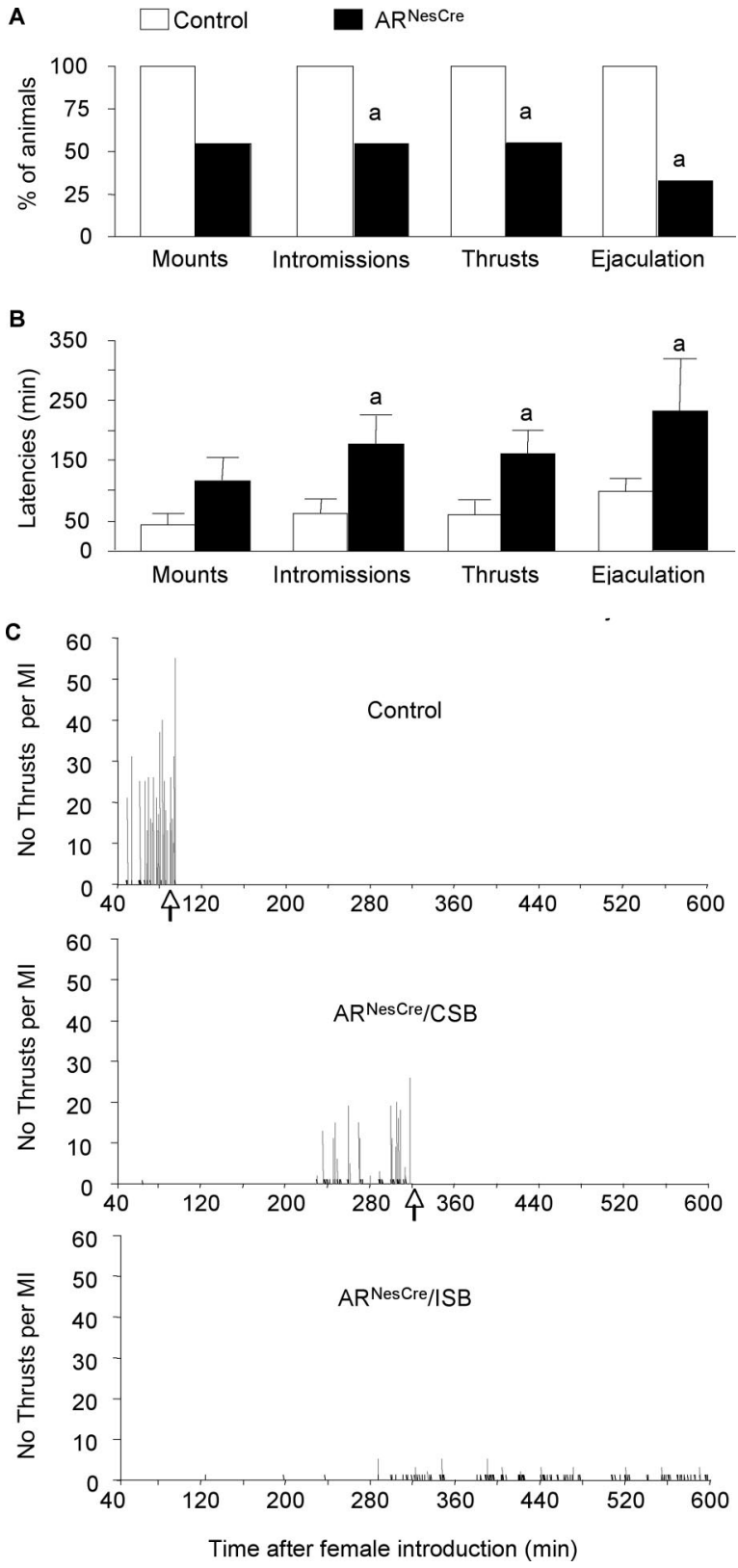

Figure 4. Male sexual behavior of control and $A R^{\text {NesCre }}$ mice measured in a $10 \mathrm{~h}$ test. $\boldsymbol{A}$, Percentage of males showing mounts, mounts with intromissions, thrusts with intromissions, and ejaculation. $\boldsymbol{B}$, Latency to the first mount (without intromission), intromission, thrust, and ejaculation for mice that displayed complete sexual behavior ( $n=9-11$ per genotype; ${ }^{a} p<$ 0.05 vs control mice). $C$, Representative time courses of male sexual behavior of control and mutant males showing complete (CSB) or incomplete (ISB) sexual behavior. The occurrences of mounts without intromissions (black lines), mounts with intromissions (MI) (gray lines), and ejaculation (arrows) within the $600 \mathrm{~min}$ of the test are indicated. The total number of thrusts for each Ml is represented on the $y$-axis.

associated with a reduced number of mounts with intromissions and thrusts (Fig. 4C, Table 2).

\section{Erectile activity}

We investigated whether the disrupted performance of $\mathrm{AR}^{\mathrm{Nes} C r e}$ mice could be related to an erectile dysfunction. In a first attempt to answer this question, we measured the intromission ratio, a parameter generally used to evaluate the efficiency of erection in copula (Agmo, 1997; Cruz et al., 1999), and the thrusting train, defined as the number of thrusts per second during an intromis- 
sion act. Both the intromission ratio $(\mathrm{Ta}-$ ble 2$)$ and the thrusting train $(0.99 \pm 0.05$ thrusts/s vs $1.22 \pm 0.05 ; p<0.01)$ were significantly decreased in $\mathrm{AR}^{\mathrm{Nes} C r e}$ mice, thereby suggesting a reduced erectile activity of $\mathrm{AR}^{\mathrm{Nes} C r e}$ males. We thus scored grooming erection during mating. For both control and mutant males, the first grooming penile erection followed the first intromission. However, a significantly increased latency was observed for $\mathrm{AR}^{\mathrm{Nes} C r e}$ mice $(182.3 \pm 47.7 \mathrm{~min}$ vs $66.7 \pm 22.8$ $\min ; p<0.05)$. Furthermore, the mean length of grooming erection was significantly reduced for $\mathrm{AR}^{\mathrm{NesCre}}$ mice $(9.0 \pm 0.6 \mathrm{~s}$ vs $14.0 \pm 1.7 \mathrm{~s} ; p<0.05)$.

Aggressive behavior

We also tested the effects of $A R$ gene inactivation in the nervous system on aggression, another sexually dimorphic behavior, by using the resident-intruder paradigm over 3 consecutive days. All resident males exhibited anogenital chemoinvestigation toward intruder mice with a comparable mean latency to the first sniff (Fig. 5A). However, the first contact with intruder mice clearly enhanced the aggressive behavior of control males, while it had no effect on mutant males. First, if only $30 \%$ of control males and $40 \%$ of $\mathrm{AR}^{\text {NesCre }}$ mice attacked on day 1 , this proportion reached $80-90 \%$ on days 2 and 3 among the control group, while it remained unchanged for mutant mice (Fig. $5 B$ ). Second, control mice that exhibited an aggressive behavior on day 1 attacked faster the following days (Fig. $5 C$ ), whereas no difference in latency to attack was observed for $\mathrm{AR}^{\mathrm{Nes} C r e}$ mice (Fig. $5 C$ ).

\section{Unaltered olfactory preference and neuronal activity after exposure to female pheromones}

In rodents, masculine behaviors are activated by olfactory cues. Pheromonal cues are transmitted from the main olfactory epithelium and vomeronasal organ to, respectively, the main and accessory olfactory bulbs, then to chemosensory responsive nuclei in MA, septum, BNST, and MPOA, where they are processed in behavioral responses. We thus tested whether $\mathrm{AR}^{\mathrm{Nes} C r e}$ males show partner preference when given a choice between clean, male-soiled, and female-soiled bedding. The total time spent sniffing containers was similar between sexually experienced control and $\mathrm{AR}^{\mathrm{NesCre}}$ mice (188.5 $\pm 10.1 \mathrm{~s}$ for control vs $185.5 \pm$ $10.8 \mathrm{~s}$ for mutant). There were no differences between both genotypes in the time spent chemoinvestigating either male or female-soiled bedding (Fig. 6A). However, all males spent significantly more time chemoinvestigating soiled beddings than the clean bedding, with a significant preference for bedding soiled by estrous females (Fig. 6A).

The expression of the immediate early gene c-fos, a marker of neuronal activity, was further examined in chemosensory regions involved in the expression of sexual behavior following exposure of males to clean or female-soiled bedding. Exposure to female olfactory cues increased Fos immunoreactivity in both the MA and MPOA with no gross differences between control and $\mathrm{AR}^{\text {NesCre }}$ mice (Fig. $6 B, C$ ). Similar results were obtained in the BNST (data not shown).

\section{Characterization of other behaviors}

Assessment of anxiety-related behavior in the EPM test did not reveal any differences in the total number of entries into the open arms (13 \pm 2 entries for controls vs $10 \pm 1$ entries for mutants) or
A

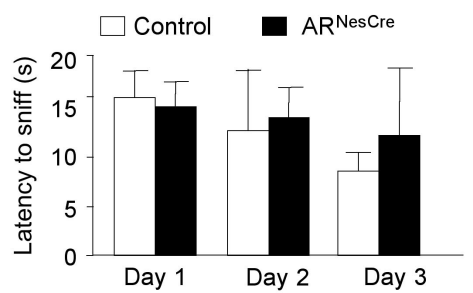

B

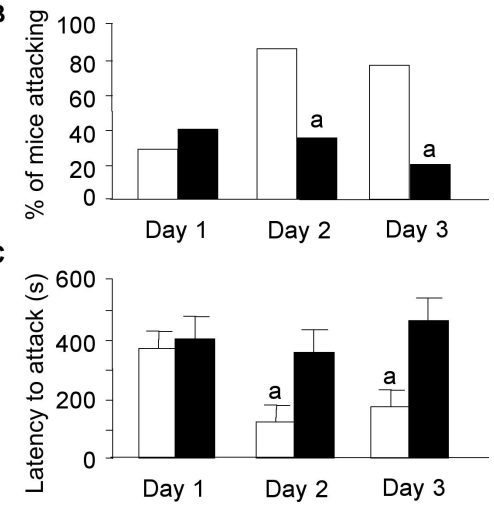

Figure 5. Aggressive behavior of mice in the resident-intruder paradigm over 3 consecutive days. $\boldsymbol{A}$, Latency to anogenital chemoinvestigation of intruders with no significant effect of genotype $\left(F_{(1,40)}=0.62, p=0.44\right)$. B , Percentage of males showing aggressive bouts on days 1,2 , and 3 ( ${ }^{a} p<0.05$ vs control mice). C, Latency to attack intruder mice. For residents that did not show aggressive behavior on days 2 and 3 of the test, the latency was 600 and $1200 \mathrm{~s}$, respectively. There was a significant effect of genotype $\left(F_{(1,24)}=8.55, p<0.05\right) . n=20$ per genotype; post hoc analysis showed significant decreased latency for control mice to attack at days 2 or 3 versus day 1 ( ${ }^{\mathrm{a}} p<0.05$ )

in the time spent in the open arms $(107.7 \pm 20.0 \mathrm{~s}$ for controls vs $108.1 \pm 29.0 \mathrm{~s}$ for mutants) between genotypes. Recording of locomotion for $14 \mathrm{~h}$ showed a progressive increase of activity, which was maximal between 9:00 P.M. ( $2 \mathrm{~h}$ after lights off) and 3:00 A.M. of the dark phase for both control and AR ${ }^{\text {NesCre }}$ mice with a significantly higher activity (a mean of $62 \%$ above control, $p<0.05$ ) observed for $\mathrm{AR}^{\text {NesCre }}$ mice during the dark phase (Fig. $7 A$ ). When measured in gonadectomized and T-treated mice, locomotor activity was comparable between both genotypes (supplemental Fig. $1 \mathrm{~B}$, available at www.jneurosci.org as supplemental material). This strongly suggests that the increased activity of intact $\mathrm{AR}^{\mathrm{Nes} C r e}$ mice was caused by their higher levels of $\mathrm{E} 2$.

These results indicate that the observed differences in maletypical behaviors among the mouse genotypes could not be attributed to an increased anxiety-related behavior or decreased locomotion of $\mathrm{AR}^{\mathrm{Nes} C r e}$ males.

\section{Effects of the NesCre transgene and DHT treatment}

To make sure that the observed alterations were specifically linked to $A R$ gene disruption in the nervous system, we first ex- 


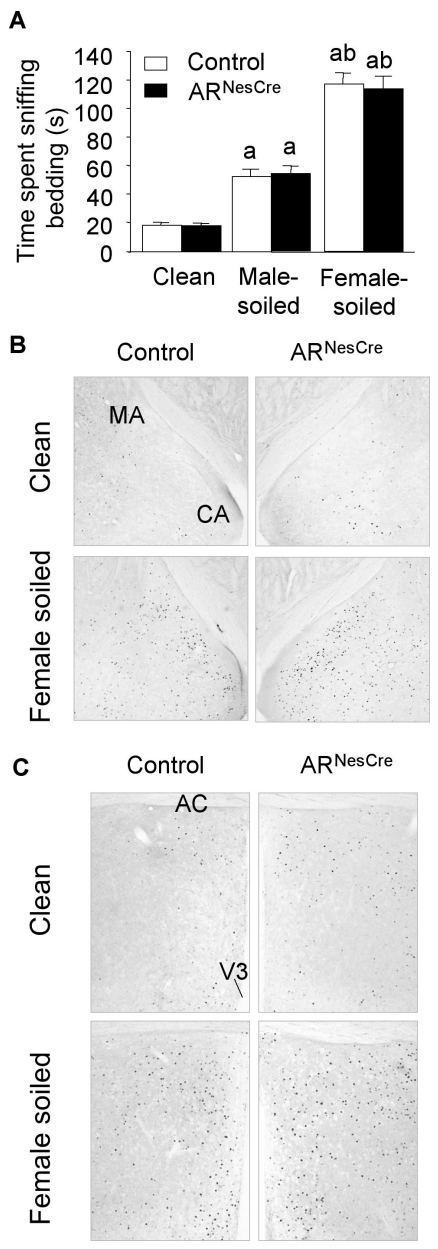

Figure 6. Olfactory preference and neuronal activation. $A$, Time spent chemoinvestigating clean, male-soiled, and female-soiled-bedding by control and $\mathrm{AR}^{\text {Nescre }}$ mice $(n=20$ per genotype). A significant effect of bedding $\left(F_{(2,76)}=143.58, p<0.0001\right)$ but not of genotype was found; post hoc analysis showed differences in the time spent sniffing the three beddings ( ${ }^{\mathrm{a}} p<$ 0.001 vs clean bedding; ${ }^{b} p<0.001$ vs male-soiled bedding). $B, C$, Representative $c-$ fos immunostaining in the medial amygdala $(\boldsymbol{B})$ and medial preoptic area $(\boldsymbol{C})$ of control and $A R^{\text {Nescre }}$ males exposed to clean or female-soiled beddings for $1 \mathrm{~h}$. CA, Cortical amygdala; $\mathrm{AC}$, anterior commissure; V3, third ventricle.

amined whether the used transgene, by itself, could have any influence on male neuroendocrine and behavioral responses. As shown in supplemental Table 2 (available at www.jneurosci.org as supplemental material), the Nes-Cre transgene alone, in the absence of any $A R$ invalidation, had no effects on the studied phenotypes. Second, we assessed the effects of the nonaromatizable DHT on sexual behavior of gonadectomized control and $\mathrm{AR}^{\mathrm{Nes} C r e}$ mice. DHT reinstated sexual behavior in $86 \%$ of mice in the control group (Fig. $7 B$ ). In contrast, none of tested $A^{\text {NesCre }}$ mice showed sexual behavior during the $10 \mathrm{~h}$ test (Fig. $7 B$ ).

\section{Quantification of ER $\alpha$-immunoreactive neurons}

Several studies highlighted the importance of ER $\alpha$ signaling pathway in T-induced masculine behaviors (Ogawa et al., 1997; Wersinger et al., 1997). We thus compared the distribution and density of ER $\alpha$-immunoreactive (IR) neurons between control and $\mathrm{AR}^{\mathrm{Nes} C r e}$ mice to check whether this $\mathrm{ER} \alpha$ signaling pathway is altered or not in $\mathrm{AR}^{\mathrm{Nes} C r e}$ mice. High nuclear $\mathrm{ER} \alpha$ immunostaining was detected in brain regions known to express this receptor, such as the MA, septum, BNST, and MPOA of both genotypes (Fig. $8 A$ ). The average number of $\mathrm{ER} \alpha$-IR cells per unit
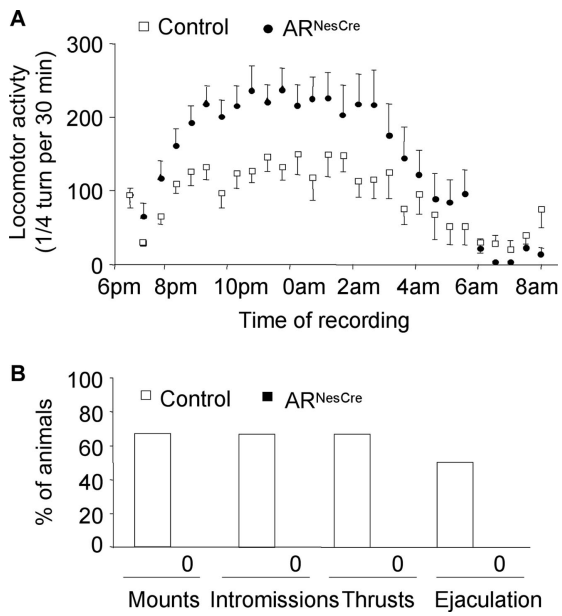

Figure 7. Locomotor activity and effect of DHT treatment on sexual behavior of control and $A R^{\text {Nescre }}$ males. $A$, Time course of an overnight $14 \mathrm{~h}$ recording of locomotor activity. The test started $1 \mathrm{~h}$ before dark phase (6:00 P.M.) and ended $1 \mathrm{~h}$ after lights on (8:00 A.M.). $n=8-13$ per genotype. $\boldsymbol{B}$, Sexual behavior of gonadectomized and DHT-treated control and AR ${ }^{\text {Nescre }}$ males in the $10 \mathrm{~h}$ test ( $n=6$ per genotype). Sexual behavior length for control mice was similar to that of intact control males $(57 \pm 15 \mathrm{~min})$.

area in brain areas involved in sexual and aggressive behaviors (MA, septum, BNST, and MPOA) was not statistically different between control and $\mathrm{AR}^{\text {NesCre }}$ mice (Fig. $8 B$ ), thereby indicating that $\mathrm{ER} \alpha$ was not decreased in $\mathrm{AR}^{\mathrm{Nes} C r e}$ mice. Rather, an increased intensity of $\mathrm{ER} \alpha$ immunoreactivity was observed in the septum and MPOA of mutant mice (Fig. $8 A$ ).

\section{Sexual and aggressive behaviors of gonadectomized and T-treated mice}

To assess, at comparable levels of $\mathrm{T}$, the effects of $A R$ invalidation on male-typical behaviors, control and mutant males were gonadectomized and supplemented with $\mathrm{T}$. As observed for intact animals, $100 \%$ of control versus $60 \%$ of $\mathrm{AR}^{\text {NesCre }}$ males exhibited sexual behavior. Again, an altered motivation, as evidenced by the increased latency to initiate sexual behavior (Fig. 9A), and decreased performance (supplemental Table 3, available at www.jneurosci.org as supplemental material) were observed for $\mathrm{AR}^{\mathrm{Nes} C r e}$ males. Mutant males also exhibited a greater latency to initiate aggressive behavior toward intruder mice (Fig. 9B). A detailed analysis of aggressive behavior indicated that $\mathrm{AR}^{\mathrm{Nes} C r e}$ males spent less time in aggressive acts (Fig. 9C) and showed less offensive and nonoffensive bouts (Fig. 9D,E). In addition, 33\% of control but none of $\mathrm{AR}^{\mathrm{Nes} C r e}$ males attempted mounts toward the intruders.

When compared with data obtained in gonadally intact mice, greater differences were observed between the two genotypes. Indeed, at $\mathrm{T}$ levels comparable to those found in gonadally intact $\mathrm{AR}^{\text {NesCre }}$ mice, as assessed by seminal vesicle weights (supplemental Fig. $1 A$, available at www.jneurosci.org as supplemental material), no changes in the phenotype were observed for mutant males, while an amelioration of sexual and aggressive behaviors was seen for control littermates. The latency to initiate both behaviors (Figs. $4 B, 9 A$ ) and mating length (Table 2; supplemental Table 3, available at www.jneurosci.org as supplemental material) were decreased for control males $(p<0.05)$. Furthermore, $100 \%$ of gonadectomized and T-treated control mice exhibited aggressive behavior since the first day in contrast to the low percentage (30\%) obtained for gonadally intact males. 


\section{Discussion}

The present study addressed the role of cerebral $\mathrm{AR}$ in $\mathrm{T}$-mediated regulation of male neuroendocrine and behavioral processes. To this aim, we generated, for the first time, mice selectively lacking $A R$ gene in the nervous system by using Cre-loxP technology, without interfering with peripheral AR functions.

\section{Requirement of cerebral $A R$ in the regulation of male neuroendocrine functions}

$A R$ disruption in the nervous system affected the negative feedback exerted by $\mathrm{T}$ on the hypothalamus-pituitary-gonad (HPG) axis since high levels of LH and intratesticular and circulating $\mathrm{T}$ were found in $\mathrm{AR}^{\mathrm{Nes} C r e}$ males. Neither the presence of AR in gonadotropes nor the unaffected hypothalamic ER $\alpha$ expression were sufficient to maintain normal $\mathrm{LH}$ and $\mathrm{T}$ levels in $\mathrm{AR}^{\mathrm{Nes} C r e}$ mice. This is in accordance with previously reported data in $\mathrm{ER} \alpha \mathrm{KO}$ males, which suggested that cerebral AR plays the primary physiological role in the steroid feedback on LH secretion (Wersinger et al., 1999). Pituitary LH synthesis and liberation are under the positive control of hypothalamic GnRH decapeptide. Our results strongly suggest that $\mathrm{T}$ through $\mathrm{AR}$ controls liberation rather than synthesis of $\mathrm{GnRH}$. It remains to be determined whether this control is exerted directly or indirectly on GnRH neurons. We did not detect AR protein in GnRH neurons of control mice (K. Raskin and S. Mhaouty-Kodja, unpublished observations). However, AR was found to be expressed in the hypothalamic KiSS-1 neurons (Smith et al., 2005), which send projections to GnRH neurons (Kinoshita et al., 2005; Clarkson and Herbison, 2006) and seem to regulate pulsatile $\mathrm{GnRH}$ and gonadotropin secretion (Messager et al., 2005). Since the Nes-Cre transgene used in the present study drives $A R$ ablation in the whole nervous system, it is possible that an altered KiSS-1 expression underlies the observed alteration of T-mediated negative feedback on HPG axis.

The reduced testis weight and sperm production of $\mathrm{AR}^{\mathrm{Nes} C r e}$ mice were secondary to $A R$ gene invalidation in the nervous system. These alterations could be related to decreased levels of IGF-I, which plays a critical role in testis growth and spermatogenesis process (Baker et al., 1996; Froment et al., 2004). However, we cannot exclude possible deleterious effects of high levels of $\mathrm{T}$ and its metabolites.

Another consequence of central $A R$ gene invalidation was the alteration of the sexually dimorphic somatotropic axis. A transient decrease in body weight was described in ubiquitous ARKO mice, but it was reversed since 12 weeks of age due to the increased adipose tissue mass and decreased lipolytic activity (Sato et al., 2003; Fan et al., 2005). In $\mathrm{AR}^{\mathrm{Nes} C r e}$ males, growth retardation was persistent until 20-30 weeks of age. This adds another argument in favor of the selectivity of $A R$ invalidation in the nervous system and strongly suggests that the mechanisms underlying the lipolytic effect of AR reside primarily in peripheral tissues. Together, these data point out the major role of central AR signaling pathway in the organizational and/or activational effects of T on somatostatin and GHRH (GH-releasing hormone) neurons (Chowen et al., 2004).

\section{Requirement of central $A R$ in the expression of masculine behaviors}

By using phenotypically male mice, we evaluated precisely the effects of central $A R$ invalidation on different components of sexual behavior. We thus report that both sexual motivation and performance were disrupted by $A R$ gene inactivation in the nervous system. The prolonged mating length probably results from a weak reinforcement of sexual motivation due to the reduced intromission behavior. The latter deficiency could be attributed, at least partly, to the disrupted penile erection of $\mathrm{AR}^{\mathrm{Nes} C r e}$ mice. Androgens, through AR activation, are known to play a major role in the masculinization of the spinal nucleus of the bulbocavernosus (SNB) (Johansen et al., 2004). Further experiments will examine whether $A R$ gene disruption in the nervous system affects AR expression in the SNB and consequently innervation of the striated muscles bulbocavernosus and levator ani attached to the penis base.

$\mathrm{AR}^{\mathrm{Nes} C r e}$ mice showed different extents of intromission and fertility alteration, but had all reduced sperm number. As it was previously reported that the fewer were the male preejaculatory intromissions, the lower was the sperm number recovered in female tract (Toner and Adler, 1986), we thus suggest that mutants with the lowest intromission behavior may correspond to the hypofertile group.

$\mathrm{AR}^{\mathrm{Nes} C r e}$ mice exhibited also a low and heterogeneous aggressive behavior in resident-intruder tests. It is of interest that disrupted sexual and aggressive behaviors of $\mathrm{AR}^{\mathrm{Nes} C r e}$ mice were associated with normal (1) discrimination between male and female nonvolatile olfactory cues, (2) chemoinvestigating behavior toward intruder mice, and (3) induction of neuronal activity, mapped by Fos immunoreactivity, in chemosensory responsive regions (MA, BNST, and MPOA) following exposure to female pheromonal cues. This leads us to suggest that deficiency in masculine behaviors is caused by an altered neuronal function in 

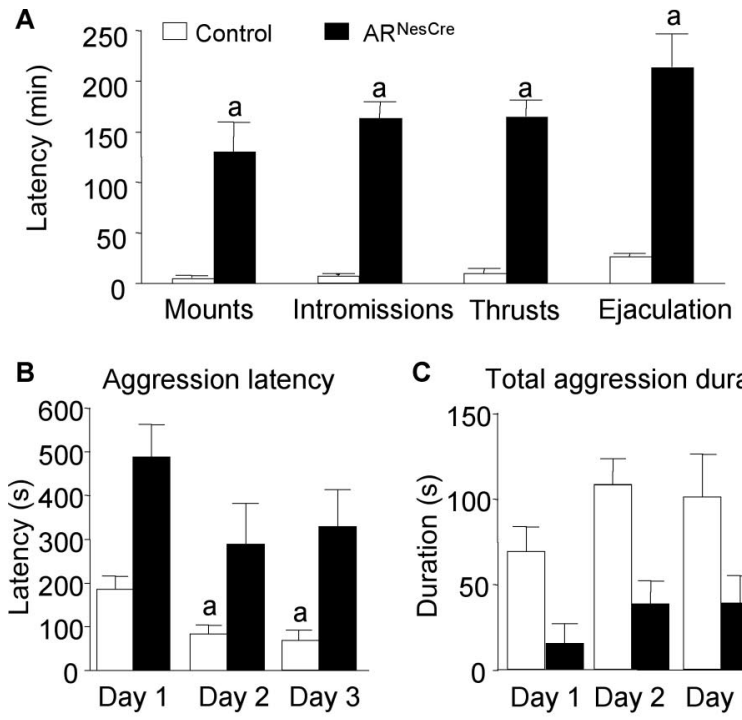

C Total aggression duration

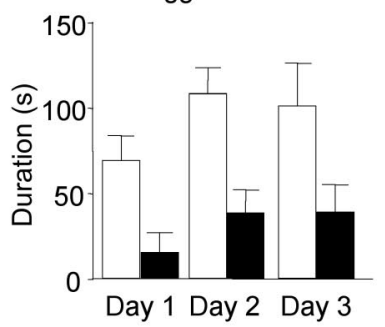

D Offensive attack bouts

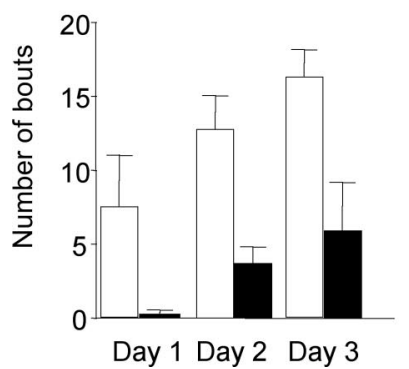

E Lunge and bite aggression bouts

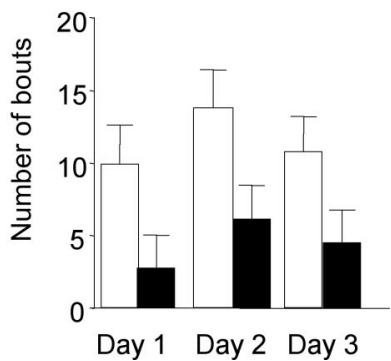

Figure 9. Male sexual and aggressive behaviors of gonadectomized and T-treated mice. $\boldsymbol{A}$, Latency to the first mount, mount with intromission, thrust, and ejaculation in the $10 \mathrm{~h}$ test ( $n=6$ per genotype; ${ }^{\mathrm{a}} p<0.05$ vs control mice). $\boldsymbol{B}$, Latency to the first aggressive behavioral act in the 10 min resident-intruder paradigm with a significant effect of genotype $\left(F_{(1,28)}=\right.$ $10.99, p=0.0051)$; post hoc analysis showed a significantly decreased latency for control mice to attack at days 2 or 3 versus day 1 ( ${ }^{a} p<0.05$ ). C, The total aggression duration was decreased in mutant mice $\left(F_{(1,28)}=20.13, p=0.0005\right)$. D, The number of offensive attacks was lower in $\operatorname{AR}^{\text {Nescre }}$ mice $\left(F_{(1,28)}=16.71, p=0.0011\right)$. $E$, The number of lunges and bites was reduced for $\operatorname{AR}^{\text {Nescre }}$ males $\left(F_{(1,28)}=20.13, p=0.0005\right) \cdot n=8$ per genotype.

chemosensory responsive regions, downstream of the olfactory bulb. To verify this hypothesis, further studies will address volatile odors.

Previous studies in Tfm mice reported a minor contribution of $\mathrm{AR}$ in the display of aggressive and coital behaviors (Scordalakes and Rissman, 2004; Bodo and Rissman, 2007) and a major role in partner preference (Bodo and Rissman, 2007). This discrepancy with our results could rely on differences between ubiquitous and nervous system-specific $A R$ mutations. In olfactory preference tests similar to that performed in the present study, $\mathrm{ER} \alpha \mathrm{KO}$ mice were unable to discriminate between maleand female-soiled bedding (Wersinger and Rissman, 2000a). The similarity between $\mathrm{Tfm}$ and $\mathrm{ER} \alpha \mathrm{KO}$ mice in terms of lack of partner preference (Wersinger and Rissman, 2000a; Bodo and Rissman, 2007) leads us to suggest that brain masculinization by T-mediated activation of ER signaling pathway during the perinatal period is not comparable between $\mathrm{Tfm}$ and $\mathrm{AR}^{\mathrm{Nes} C r e}$ mice. Indeed, although indirect evidence supported the conclusion of unaffected T production in newborn testes (Goldstein and Wilson, 1972), it is still unknown whether circulating T levels are in the normal range in perinatal $\mathrm{Tfm}$ mice. In $\mathrm{AR}^{\mathrm{Nes} C r e}$ mice, masculine behaviors were altered despite high levels of $\mathrm{T}$ and its me- tabolite E2. At comparable levels of T, sexual and aggressive behaviors of gonadectomized and T-treated control mice were greatly ameliorated. The inability of DHT to reinstate sexual behavior in gonadectomized $\mathrm{AR}^{\mathrm{Nes} C r e}$ mice strongly suggests that the remaining sexual behavior of intact $A R^{\text {NesCre }}$ mice is probably due to the only activation of $\operatorname{ER} \alpha$ signaling pathway. It is, however, important to note that $\operatorname{ER} \alpha$ was not sufficient to compensate for the absence of AR. In line with our data, administration of E2 with DHT to castrated males, but not E2 alone, induced the same levels of masculine sexual behavior as those observed after treatment with $\mathrm{T}$ or in intact males (Cooke et al., 2003; BurnsCusato et al., 2004; Arteaga-Silva et al., 2007). Nevertheless, as it has been previously shown that androgens upregulate aromatase expression (Yamada et al., 1993; Roselli et al., 1997), it would be interesting to examine whether brain aromatase expression is affected in $\mathrm{AR}^{\mathrm{Nes} C r e}$ mice.

In conclusion, we report here a pertinent genetic model that allows exploring the specific involvement of central AR in $\mathrm{T}$-induced effects in the nervous system. Our results support the idea that cerebral AR and ER signaling pathways play complementary roles in the masculinization of the nervous system during the perinatal period and/or the regulation of neuroendocrine and behavioral processes at the adult stage. The relative contribution of each of cerebral AR or ER in T-induced effects might differ between brain areas. Indeed, as strongly suggested in the present study, regulation of the somatotropic axis by $\mathrm{T}$ seems to be exclusively dependent on AR activation, while both AR and ER signaling pathways are required for the expression of masculine behaviors in mice. A precise comparison of the involvement of each of these signaling pathways in the latter responses needs further generation of conditional ERKO mutants in the nervous system.

\section{References}

Agmo A (1997) Male rat sexual behavior. Brain Res Brain Res Protoc 1:203-209.

Arteaga-Silva M, Rodríguez-Dorantes M, Baig S, Morales-Montor J (2007) Effects of castration and hormone replacement on male sexual behavior and pattern of expression in the brain of sex-steroid receptors in BALB/c AnN mice. Comp Biochem Physiol A Mol Integr Physiol 147:607-615.

Baker J, Hardy MP, Zhou J, Bondy C, Lupu F, Bellvé AR, Efstratiadis A (1996) Effects of an Igfl gene null mutation on mouse reproduction. Mol Endocrinol 10:903-918.

Bakker J, Honda S, Harada N, Balthazart J (2002) Sexual partner preference requires a functional aromatase (cyp19) gene in male mice. Horm Behav 42:158-171.

Bodo C, Rissman EF (2007) Androgen receptor is essential for sexual differentiation of responses to olfactory cues in mice. Eur J Neurosci 25:2182-2190.

Bradford MM (1976) A rapid and sensitive method for the quantitation of microgram quantities of protein utilizing the principle of protein-dye binding. Anal Biochem 72:248-254.

Burns-Cusato M, Scordalakes EM, Rissman EF (2004) Of mice and missing data: what we know (and need to learn) about male sexual behavior. Physiol Behav 83:217-232.

Caraty A, Antoine C, Delaleu B, Locatelli A, Bouchard P, Gautron JP, Evans NP, Karsch FJ, Padmanabhan V (1995) Nature and bioactivity of gonadotropin-releasing hormone $(\mathrm{GnRH})$ secreted during the $\mathrm{GnRH}$ surge. Endocrinology 136:3452-3460.

Chang C, Chen YT, Yeh SD, Xu Q, Wang RS, Guillou F, Lardy H, Yeh S (2004) Infertility with defective spermatogenesis and hypotestosteronemia in male mice lacking the androgen receptor in Sertoli cells. Proc Natl Acad Sci U S A 101:6876-6881.

Chowen JA, Frago LM, Argente J (2004) The regulation of GH secretion by sex steroids. Eur J Endocrinol 151 [Suppl 3]:U95-U100.

Clarkson J, Herbison AE (2006) Postnatal development of kisspeptin neurons in mouse hypothalamus; sexual dimorphism and projections to 
gonadotropin-releasing hormone neurons. Endocrinology 147:5817-5825.

Cooke BM, Breedlove SM, Jordan CL (2003) Both estrogen receptors and androgen receptors contribute to testosterone-induced changes in the morphology of the medial amygdala and sexual arousal in male rats. Horm Behav 43:336-346.

Cruz MR, Liu YC, Manzo J, Pacheco P, Sachs BD (1999) Peripheral nerves mediating penile erection in the rat. J Auton Nerv Syst 76:15-27.

De Gendt K, Swinnen JV, Saunders PT, Schoonjans L, Dewerchin M, Devos A, Tan K, Atanassova N, Claessens F, Lécureuil C, Heyns W, Carmeliet P, Guillou F, Sharpe RM, Verhoeven G (2004) A Sertoli cell-selective knockout of the androgen receptor causes spermatogenic arrest in meiosis. Proc Natl Acad Sci U S A 101:1327-1332.

Fan W, Yanase T, Nomura M, Okabe T, Goto K, Sato T, Kawano H, Kato S, Nawata H (2005) Androgen receptor null male mice develop late-onset obesity caused by decreased energy expenditure and lipolytic activity but show normal insulin sensitivity with high adiponectin secretion. Diabetes 54:1000-1008.

Froment P, Staub C, Hembert S, Pisselet C, Magistrini M, Delaleu B, Seurin D, Levine JE, Johnson L, Binoux M, Monget P (2004) Reproductive abnormalities in human insulin-like growth factor-binding protein-1 transgenic male mice. Endocrinology 145:2080-2091.

Goldstein JL, Wilson JD (1972) Studies on the pathogenesis of the pseudohermaphroditism in the mouse with testicular feminization. J Clin Invest 51:1647-1658.

Johansen JA, Jordan CL, Breedlove SM (2004) Steroid hormone masculinization of neural structure in rats: a tale of two nuclei. Physiol Behav 83:271-277.

Kinoshita M, Tsukamura H, Adachi S, Matsui H, Uenoyama Y, Iwata K, Yamada S, Inoue K, Ohtaki T, Matsumoto H, Maeda K (2005) Involvement of central metastin in the regulation of preovulatory luteinizing hormone surge and estrous cyclicity in female rats. Endocrinology 146:4431-4436.

Kunieda T, Xian M, Kobayashi E, Imamichi T, Moriwaki K, Toyoda Y (1992) Sexing of mouse preimplantation embryos by detection of $\mathrm{Y}$ chromosome-specific sequences using polymerase chain reaction. Biol Reprod 46:692-697.

Le Roy I, Pothion S, Mortaud S, Chabert C, Nicolas L, Cherfouh A, Roubertoux PL (2000) Loss of aggression, after transfer onto a C57BL/6J background, in mice carrying a targeted disruption of the neuronal nitric oxide synthase gene. Behav Genet 30:367-373.

Liere P, Akwa Y, Weill-Engerer S, Eychenne B, Pianos A, Robel P, Sjövall J, Schumacher M, Baulieu EE (2000) Validation of an analytical procedure to measure trace amounts of neurosteroids in brain tissue by gas chromatography-mass spectrometry. J Chromatogr B Biomed Sci Appl 739:301-312.

Lyon MF, Hawkes SG (1970) X-linked gene for testicular feminization in the mouse. Nature 227:1217-1219.

Matsumoto T, Takeyama K, Sato T, Kato Sb (2003) Androgen receptor functions from reverse genetic models. J Steroid Biochem Mol Biol 85:95-99.

Meffre D, Pianos A, Liere P, Eychenne B, Cambourg A, Schumacher M, Stein DG, Guennoun R (2007) Steroid profiling in brain and plasma of male and pseudopregnant female rats after traumatic brain injury: analysis by gas chromatography/mass spectrometry. Endocrinology 148:2505-2517.

Messager S, Chatzidaki EE, Ma D, Hendrick AG, Zahn D, Dixon J, Thresher RR, Malinge I, Lomet D, Carlton MB, Colledge WH, Caraty A, Aparicio SA (2005) Kisspeptin directly stimulates gonadotropin-releasing hormone release via G protein-coupled receptor 54 . Proc Natl Acad Sci U S A 102:1761-1766.
Moore JP Jr, Wray S (2000) Luteinizing hormone-releasing hormone (LHRH) biosynthesis and secretion in embryonic LHRH. Endocrinology 141:4486-4495.

Ogawa S, Lubahn DB, Korach KS, Pfaff DW (1997) Behavioral effects of estrogen receptor gene disruption in male mice. Proc Natl Acad Sci U S A 94:1476-1481.

Ono S, Geller LN, Lai EV (1974) TfM mutation and masculinization versus feminization of the mouse central nervous system. Cell 3:235-242.

Phoenix CH, Goy RW, Gerall AA, Young WC (1959) Organizing action of prenatally administered testosterone propionate on the tissues mediating mating behavior in the female guinea pig. Endocrinology 65:369-382.

Rampin O, Jérôme N, Suaudeau C (2003) Proerectile effects of apomorphine in mice. Life Sci 72:2329-2336.

Rampin O, Jérôme N, Briant C, Boué F, Maurin Y (2006) Are oestrus odours species specific? Behav Brain Res 172:169-172.

Roselli CE, Abdelgadir SE, Resko JA (1997) Regulation of aromatase gene expression in the adult rat brain. Brain Res Bull 44:351-357.

Salomon L, Lanteri C, Glowinski J, Tassin JP (2006) Behavioral sensitization to amphetamine results from an uncoupling between noradrenergic and serotonergic neurons. Proc Natl Acad Sci U S A 103:7476-7481.

Sato T, Matsumoto T, Yamada T, Watanabe T, Kawano H, Kato S (2003) Late onset of obesity in male androgen receptor-deficient (AR KO) mice. Biochem Biophys Res Commun 300:167-171.

Sato T, Matsumoto T, Kawano H, Watanabe T, Uematsu Y, Sekine K, Fukuda T, Aihara K, Krust A, Yamada T, Nakamichi Y, Yamamoto Y, Nakamura T, Yoshimura K, Yoshizawa T, Metzger D, Chambon P, Kato S (2004) Brain masculinization requires androgen receptor function. Proc Natl Acad Sci U S A 101:1673-1678.

Scordalakes EM, Rissman EF (2004) Aggression and arginine vasopressin immunoreactivity regulation by androgen receptor and estrogen receptor alpha. Genes Brain Behav 3:20-26.

Smith JT, Dungan HM, Stoll EA, Gottsch ML, Braun RE, Eacker SM, Clifton DK, Steiner RA (2005) Differential regulation of KiSS-1 mRNA expression by sex steroids in the brain of the male mouse. Endocrinology 146:2976-2984.

Toner JP, Adler NT (1986) The pre-ejaculatory behavior of male and female rats affects the number of sperm in the vagina and uterus. Physiol Behav 36:363-367.

Tronche F, Kellendonk C, Kretz O, Gass P, Anlag K, Orban PC, Bock R, Klein R, Schütz G (1999) Disruption of the glucocorticoid receptor gene in the nervous system results in reduced anxiety. Nat Genet 23:99-103.

Wersinger SR, Rissman EF (2000a) Oestrogen receptor alpha is essential for female-directed chemo-investigatory behaviour but is not required for the pheromone-induced luteinizing hormone surge in male mice. J Neuroendocrinol 12:103-110.

Wersinger SR, Rissman EF (2000b) Dopamine activates masculine sexual behavior independent of the estrogen receptor $\alpha$. J Neurosci 20:4248-4254.

Wersinger SR, Sannen K, Villalba C, Lubahn DB, Rissman EF, De Vries GJ (1997) Masculine sexual behavior is disrupted in male and female mice lacking a functional estrogen receptor alpha gene. Horm Behav 32:176-183.

Wersinger SR, Haisenleder DJ, Lubahn DB, Rissman EF (1999) Steroid feedback on gonadotropin release and pituitary gonadotropin subunit mRNA in mice lacking a functional estrogen receptor alpha. Endocrine 11:137-143.

Yamada K, Harada N, Tamaru M, Takagi Y (1993) Effects of changes in gonadal hormones on the amount of aromatase messenger RNA in mouse brain diencephalon. Biochem Biophys Res Commun 195:462-468. 